Р.С. Гребеля, І.І. Слюсарь, В.І. Слюсар

Полтавський національний технічний університет імені Юрія Кондратюка, Полтава

\title{
ДОСЛІДЖЕННЯ ВПЛИВУ ПЕРЕКРИТТЯ ЕЛЕМЕНТІВ ДІЕЛЕКТРИЧНИХ РЕЗОНАТОРНИХ АНТЕН НА ОСНОВІ УСІЧЕНОГО КОНУСУ
}

\begin{abstract}
Розглянуто характеристики квазіфрактальних діелектричних резонаторних антен (ДРА) на основі усіченого конусу в залежності від глибини перекриття їх елементів. При иььму досліджені два варіанти антен: більшим діаметром вгору та більшим діаметром до низу. Оцінка та порівняння антен здійснювалися за такими парламентами: амплітудно-частотна характеристика, діаграма спрямованості та коефіцієнт стоячої хвилі. Очінка зазначених параметрів проводилася за допомогою пакету програм Ansoft HFSS.
\end{abstract}

Ключові слова: антена, АЧХ, ДС, фрактал, Ansoft HFSS, DRA.

\section{Вступ}

Стрімке розширення функціоналу телекомунікаційної апаратури супроводжується одночасним посиленням вимоги щодо іiі мініатюризації. Даний аспект технологічного розвитку спонукає виробників до пошуку нових підходів до побудови антенних систем.

При цьому, основний акцент робиться на широкосмуговості та багатодіапазонності. В даному сенсі, досить привабливими $\epsilon$ високоефективні діелектричні резонаторні антени (ДРА), що характеризуються компактними розмірами, можливістю формування заданої діаграми спрямованості (ДС) i роботою в широкому частотному спектрі [1]. Як відомо, в даному типі антен використовується діелектрик, 3 якого легко формуються їх елементи: паралелепіпеди, циліндри, конуси, напівсфери та iн. [2].

3 метою реалізації багатодіапазонності при проектуванні ДРА можливо використовувати так званий «фрактальний підхід» [3-5]. Перш за все, він спирається на застосування відомих геометричних фракталів в антенних рішеннях. Існуючі чисельні публікації результатів імітаційного моделювання та експериментів свідчать, що фрактальні антени дозволяють отримати практично той же коефіцієнт підсилення, що і звичайні, але при менших габаритах, що важливо для мобільних телекомунікаційних систем.

В свою чергу, для запропонованих фрактальних ДРА буде досить важко спрогнозувати характеристики через їх залежність від геометричних форм елементів, їх кількості, розміщення цих елементів один відносно одного, а також глибини та наявності перекриття елементів антени. Виходом 3 цього є використання методів чисельного моделювання [6].
Таким чином, актуальним завданням є розробка антен, що мають одночасно малі габарити, необхідний коефіцієнт посилення та здатність працювати в широкому спектрі частот. При цьому, доцільно дослідити вплив зміни геометрії багатоелементної ДРА на іiї просторово-частотні характеристики.

Мета роботи: визначення впливу конструкції та рівня накладання елементів ДРА на базі усіченого конусу на характеристики антени.

\section{Основна частина}

На даний час для моделювання антенної техніки існує кілька пакетів програмного забезпечення. Відносно ДРА, досить привабливим $є$ пакет Ansoft HFSS [7].

3 метою розширення схемотехніки ДРА в роботі запропоновано спиратись на квазіфрактальну геометрію, для якої існування рекурсивного співвідношення фрактальних ітерацій є необов'язковим.

Для повноти опису впливу геометрії ДРА, крім ДС доцільно розглянути частотні характеристики антен у вигляді частотних залежностей коефіцієнта підсилення (далі - АЧХ) та коефіцієнту стоячої хвилі (КСХ). Згідно [8], для формування ДРА використовується усічений конус 3 умовного діелектричного матеріалу, діелектрична проникність якого $\varepsilon=50$. Всі досліджені варіанти ДРА містять 5 елементів, які розташовані на одній горизонтальній поверхні, мають однакові геометричні розміри та зроблені з одного матеріалу.

Розміри базового елементу антени з метою аналізу загальних залежностей обрані наступними:

більший діаметр - 40,

менший діаметр - 30,

висота - 15 мм.

Живлення підводиться тільки до центрального елемента антени. 
Під час досліджень оцінювались залежності просторово-частотних характеристик ДРА від висоти конусу, схеми живлення та, особливо, глибини перекриття центрального елемента периферійними.

Враховуючі наведені положення, в пакеті Ansoft HFSS була отримана модель ДРА, що відповідає рис. 1. Проаналізувавши результати 3 дослідження антени, можна зробити такі висновки. ДРА має ДС, що близька за формою до однопроменевої ДС звичайного диполя, резонансна частота знаходиться на відмітці 10,2 ГГц. АЧХ 5-елементної антени має два виражені резонанси. Якщо необхідно, робочу частоту можна змінити за допомогою варіації розміру антенного елементу (АЕ), у тому числі з метою досягнення злиття резонансів у широкосмугову ділянку. Значення коефіцієнта підсилення хоча і фіксується на досить високому рівні, та все ж таки має недостатні для таких високих частот величини.

Характер впливу висоти АЕ на форму ДС наведений на рис. 2.
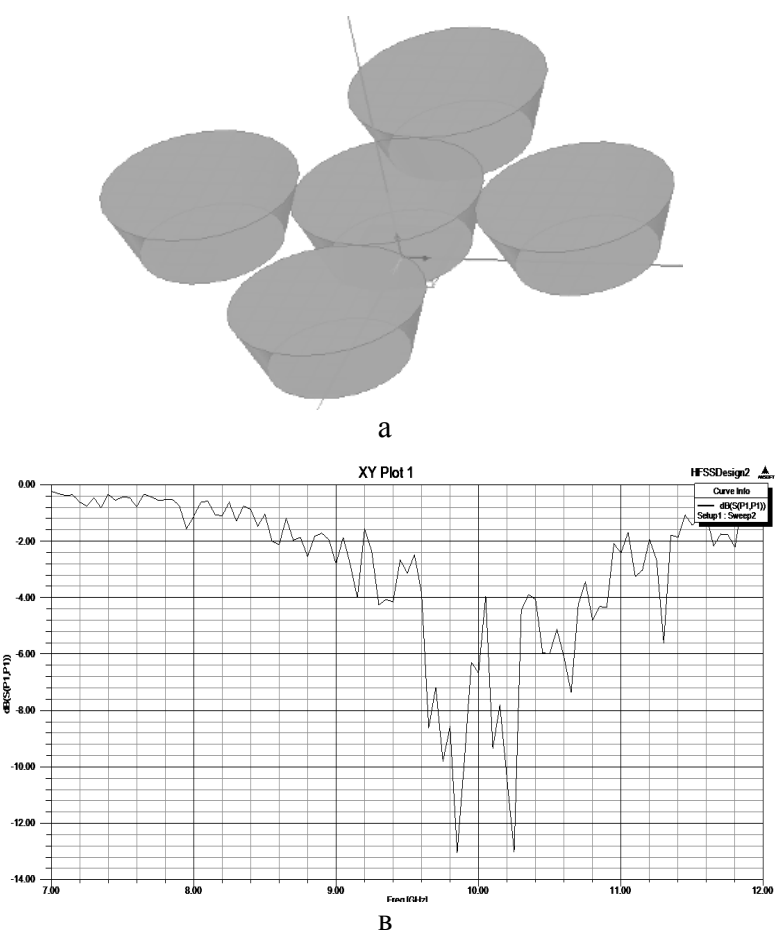

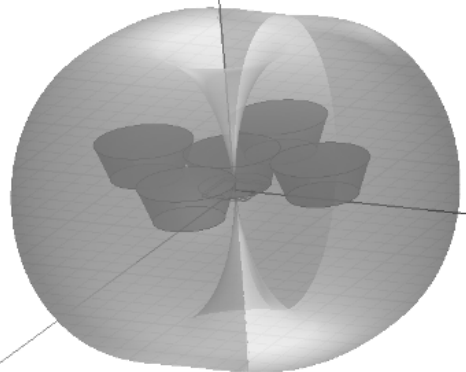

б

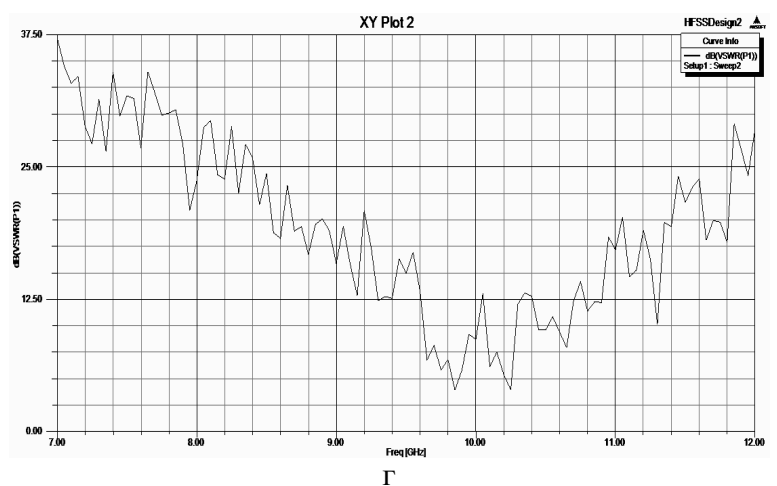

Рис. 1. Базова модель ДРА: а - компоновка; б - ДС; в - АЧХ; г - КСХ
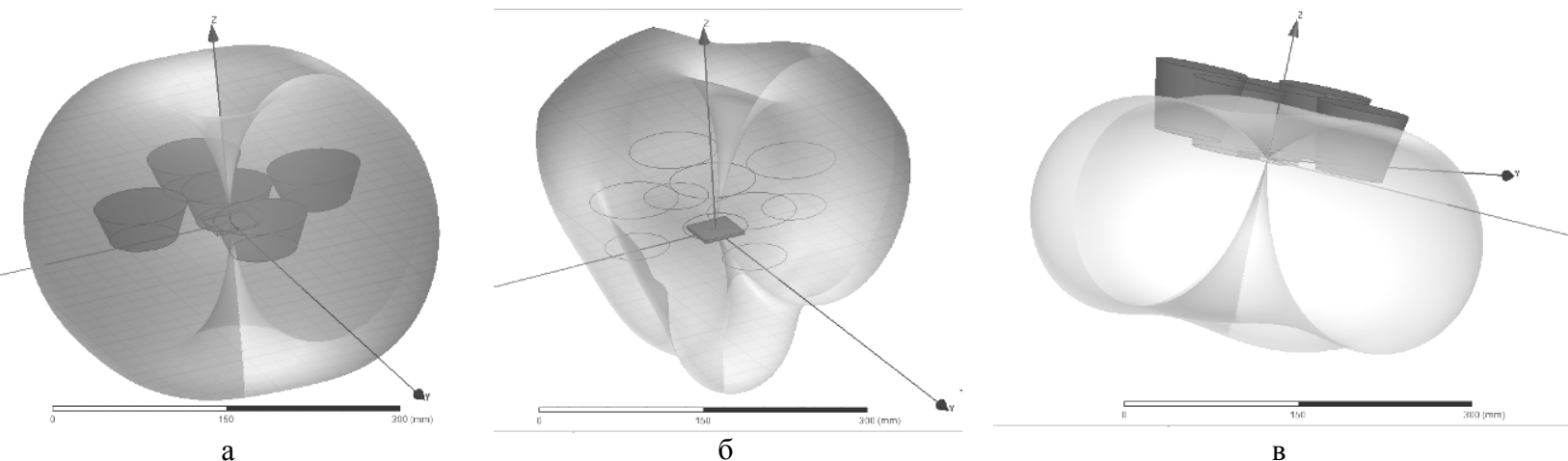

Рис. 2. Вплив висоти АЕ на форму ДС: a -30 мм, б- 45 мм, в - 60 мм

При зміні значення співвідношення між діаметрами меншого та більшого основ усіченого конусу також спостерігається відхилення резонансних частот відносно початкового положення (рис. 3).

Подальшим кроком досліджень $є$ введення перекриття (10 мм в основі усічених конусів). Слід зазначити, що якщо в попередньому варіанті $\mathrm{AE}$ дотикалися один 3 одним лише в одній точці, то, в даному випадку, елементи накладаються та утворюють одну суцільну фігуру (рис. 4).

Порівняємо отримані результати.

Очевидно, що антена стала компактнішою за попередню, це $\epsilon$ важливим критерієм для сучасної техніки. 


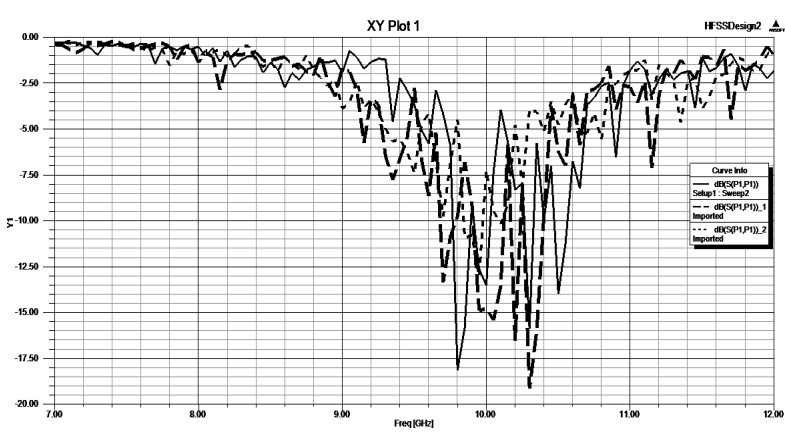

a

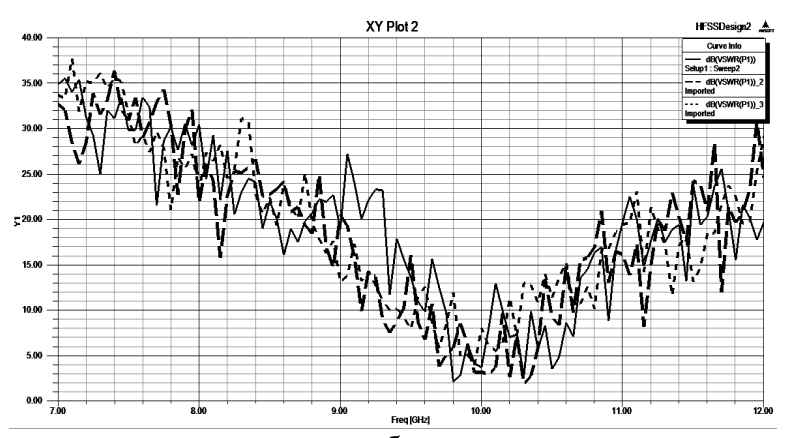

6

Рис. 3. Вплив зміни діаметру меншої основи АЕ (суцільна лінія - 10 мм; пунктирна лінія - 15 мм; крапкова лінія - 20 мм) при фіксованому діаметру більшої основи: а - АЧХ; б - КСХ

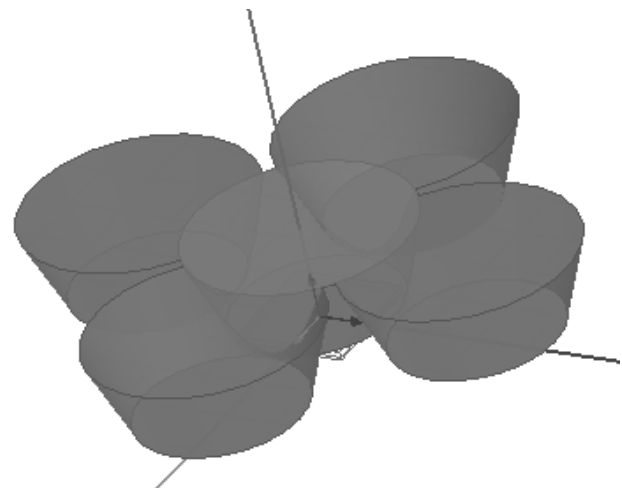

a

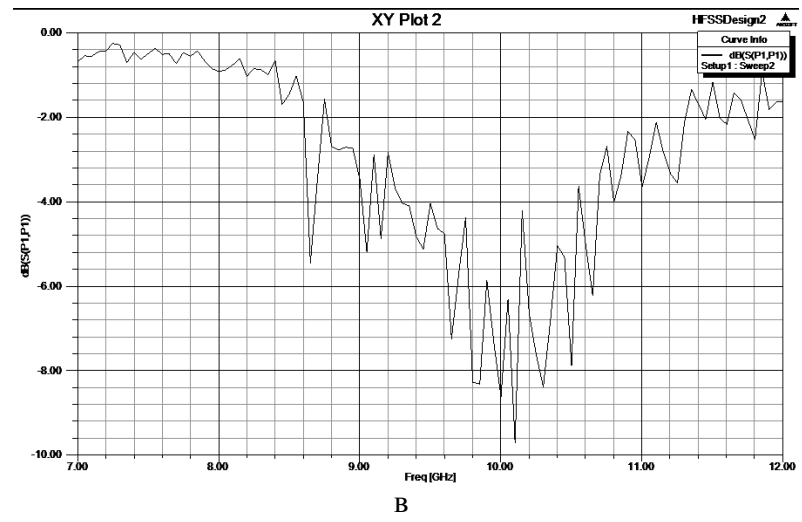

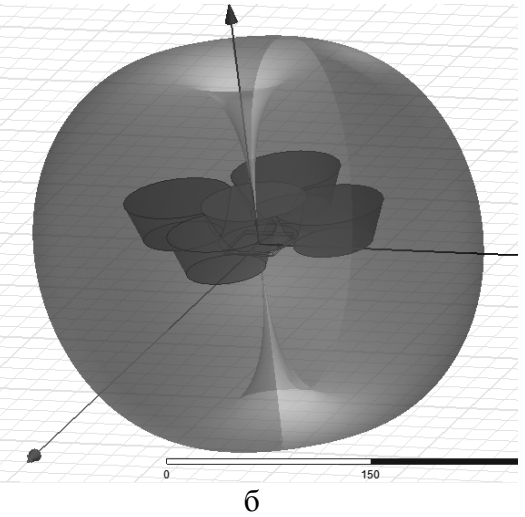

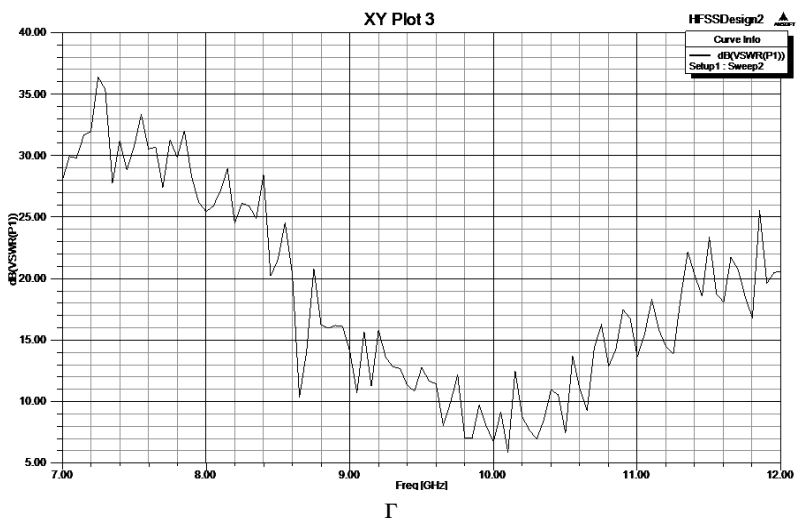

Рис. 4. ДРА з перекриттям АЕ на 10 мм:

а - компоновка; б - ДС; в - АЧХ; г - КСХ

Що ж стосується ДС, то вона майже не зазнала ніяких змін і залишилася близькою до однопроменевої. АЧХ, в свою чергу, змінилася більше, ніж ДС. В першу чергу, це стосується збільшеної смуги робочих частот ДРА. При цьому не значно змінилася основна робоча частота 310,2 до 10,1 ГГц, а також менше, ніж на 1 дБ зменшилось підсилення антени, що не є суттєвим.

Отже, антена 3 накладанням в 10 мм має трохи гірші параметри, ніж антенна без перекриття елементів.

Наступною $є$ модель 3 перекриттям АЕ на рівні 20 мм (рис. 5).

Провівши аналіз отриманих результатів, можна зробити наступні висновки. ДС, як і в двох попередніх випадках, близька до однопроменевої. 3 графіку
АЧХ видно, що робоча частота знову стала 10,2 ГГц, тобто така ж, як і в антені без накладання.

При детальнішому порівнянні АЧХ антен 3 накладанням 20 мм і без накладання, можна побачити, що робочий частотний діапазон ДРА $з$ накладанням ширший.

Однак, основна відмінність АЧХ цих антен збільшений на величину понад $70 \%$ коефіцієнт підсилення антени з накладанням, що є досить непоганим результатом.

Таким чином, три синтезовані варіанти ДРА мають такі властивості.

1. ДС у всіх трьох випадках близька до однопроменевої, що $\epsilon$ важливою умовою, в сукупності 3 малими розмірами, при використанні цих антен в мобільних пристроях. 
2. Припущення, що накладання елементів антени зможе підвищити коефіцієнт підсилення антени та вивести його на потрібний рівень виявилося справедливим і в третьому дослідженні, в якому розглянуто ДРА з перекриттям 20 мм. При цьому спостерігається збільшення рівня підсилення антени більше, ніж на $70 \%$.
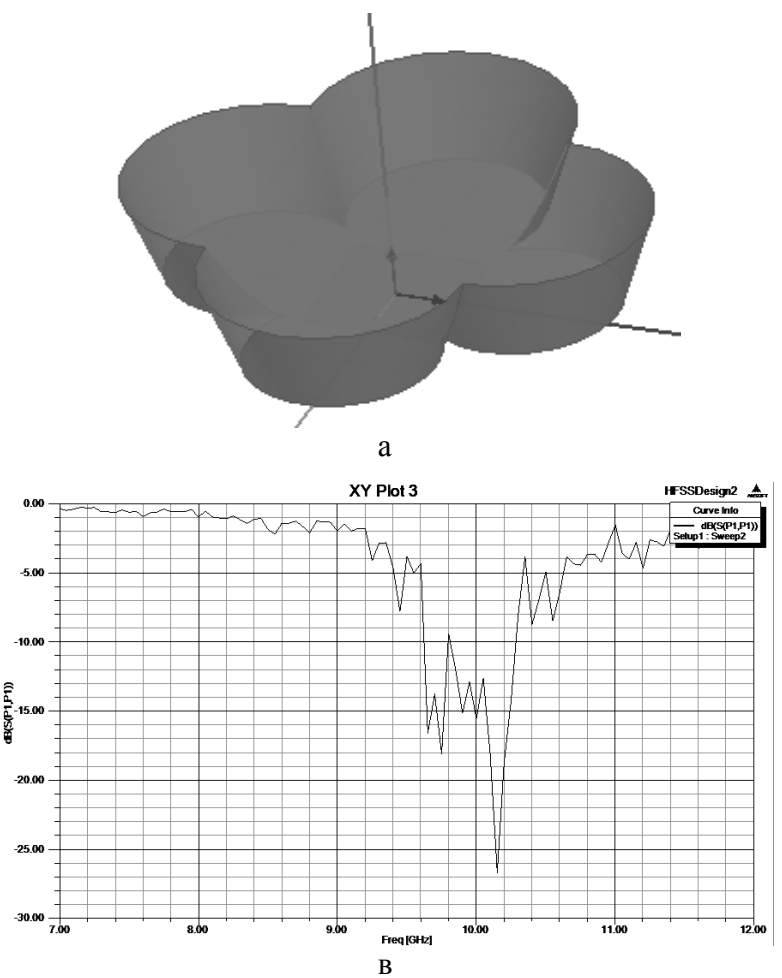

Рис. 5. ДРА з перекриттям АЕ на 20 мм: а - компоновка; б - ДС; в - АЧХ; г - КСХ
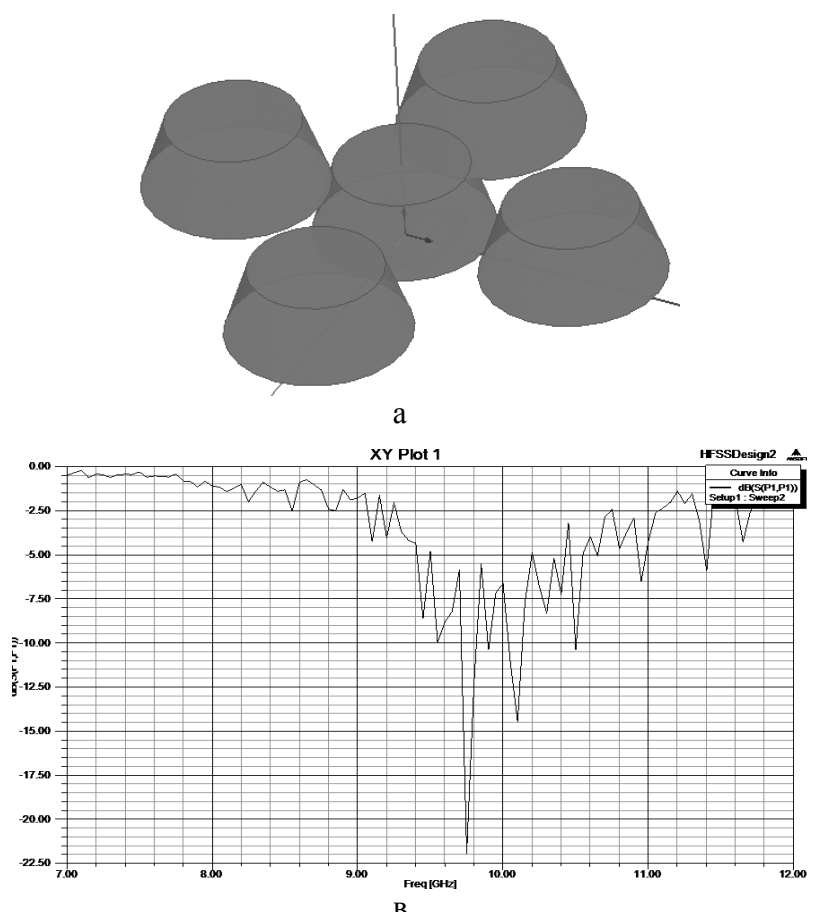

Рис. 6. Друга базова модель ДРА: а - компоновка; б - ДС; в - АЧХ; г - КСХ

Рис. 6 являє собою дзеркальне відображення попередньої версії базової моделі, в який живлення
3. При аналізі результатів моделювання підтверджено гіпотезу, що ступінь накладання елементів антени впливає на спектр робочих частот, але пошук закономірності зміни ширини спектру у цьому випадку потребує додаткових досліджень.

Надалі, слід розглянути альтернативний варіант базової компоновки ДРА, що відповідає рис. 6.
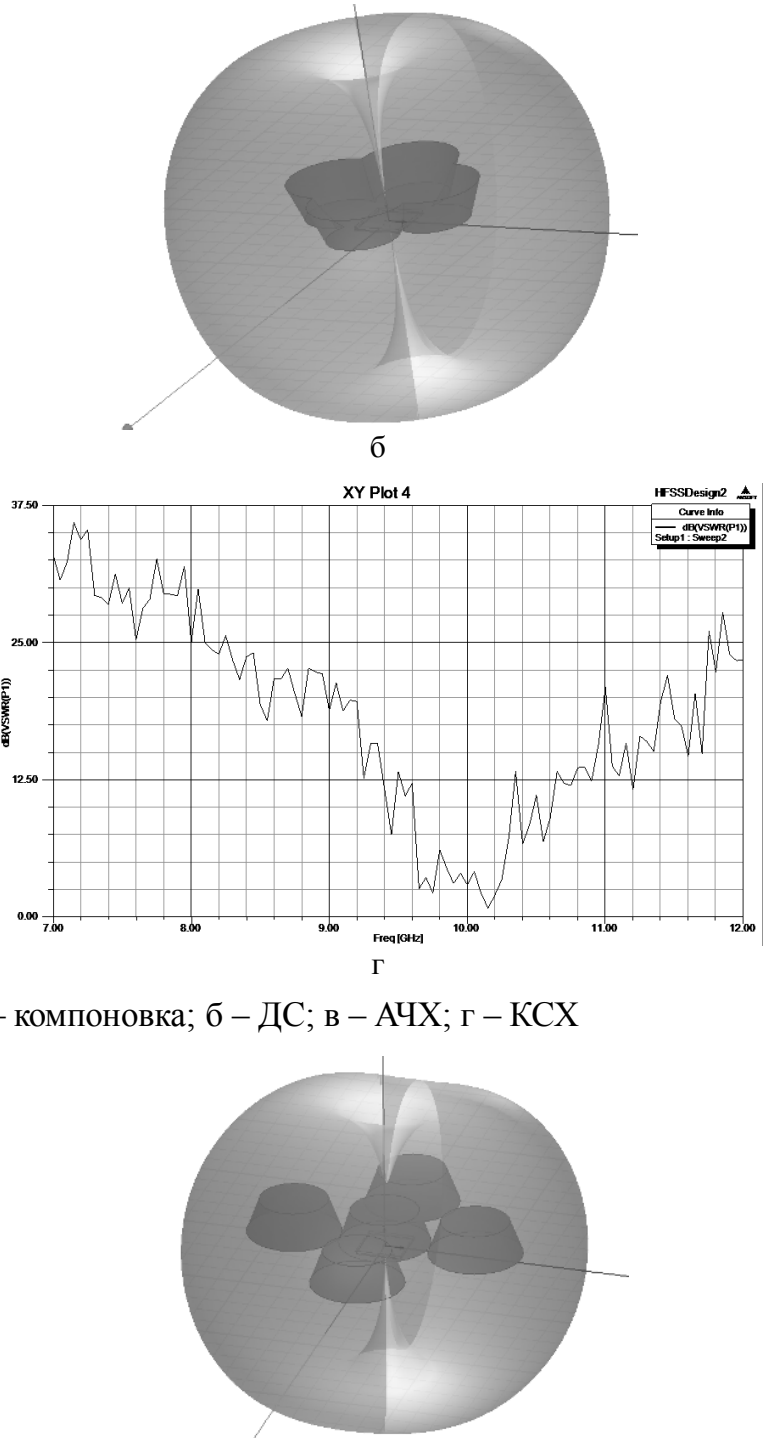

6

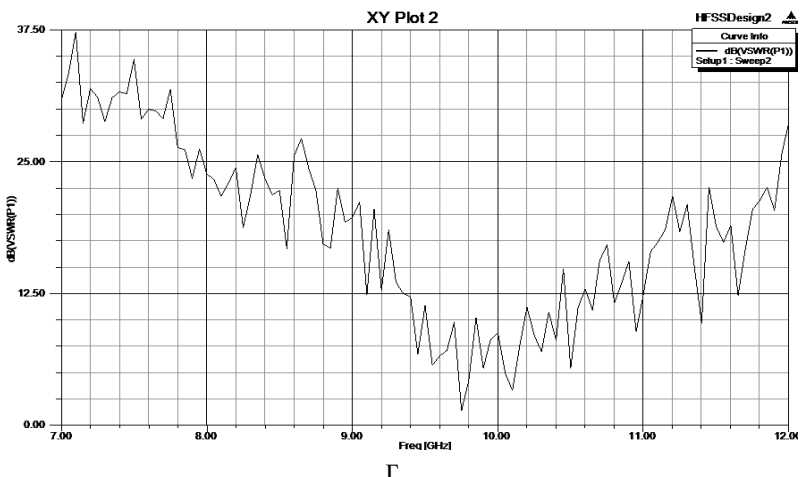

підводиться до широкої основи центрального антенного елементу. 
3 графіків видно, що коефіцієнт підсилення сягає досить високого рівня. Якщо порівнювати, то він вище на 50 \% від аналогічного конструктиву антени з більшим радіусом до гори. Також можна відмітити розширення смуги пропускання антени порівняно 3 першим типом антен.

Варіант ДРА $з$ перекриттям на 10 мм відповідає рис. 7. Як і у всіх попередніх випадках, маємо оптимальну форму ДС. 3 графіку АЧХ видно, що рівень коефіцієнту підсилення зменшився на чверть, порівняно з минулим варіантом антени. Слід зазначити, що смуга пропускання за цим параметром стала

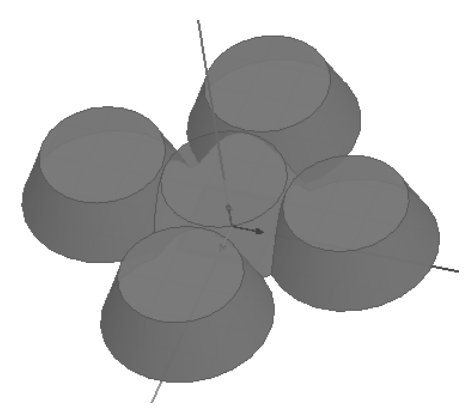

$\mathrm{a}$

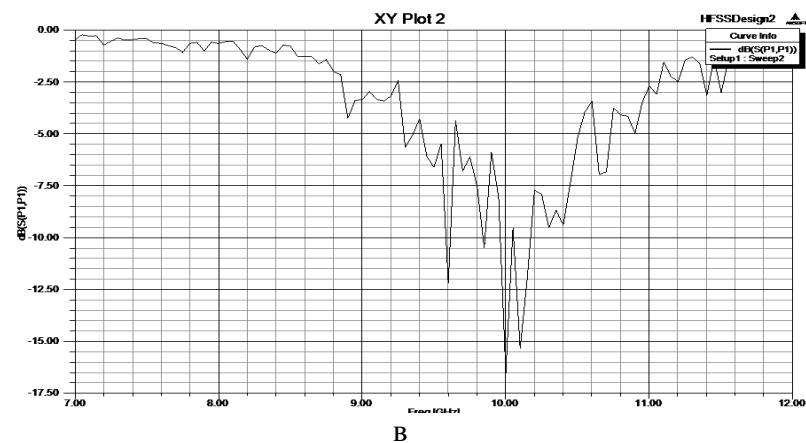

Рис. 7. Друга базова модель ДРА з перекриттям на 10 мм: а - компоновка; б - ДС; в - АЧХ; г - КСХ

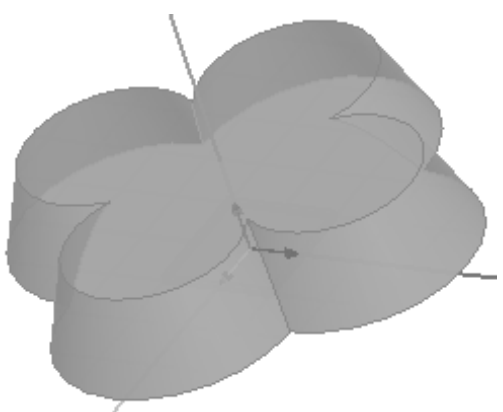

a

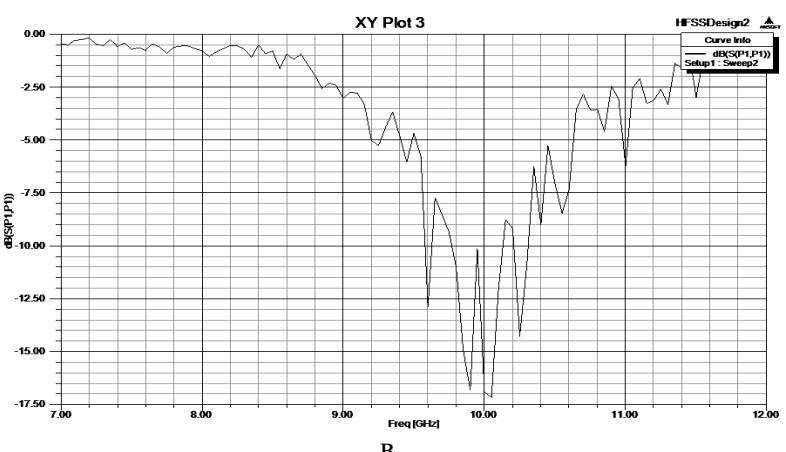

менше, порівняно 3 попередньою антеною, та наближається до значень для першої базової антени з перекриттям AE на 20 мм. Однак, якщо порівнювати ці дві антени, то в антени (див. рис. 5.в), коефіцієнт підсилення значно вищий ніж у даної. Суттєво, що всі результати отримані без вжиття додаткових заходів для узгодження DRA з фідером живлення.

Останньою серед даного типу антен розглянемо ДРА 3 перекриттям в 20 мм (рис. 8). ДС несуттєво змінилася у порівнянні з попередніми конструкціями, якщо придивитися, то в горі та внизу ДС трохи вужча ніж у інших ДРА.

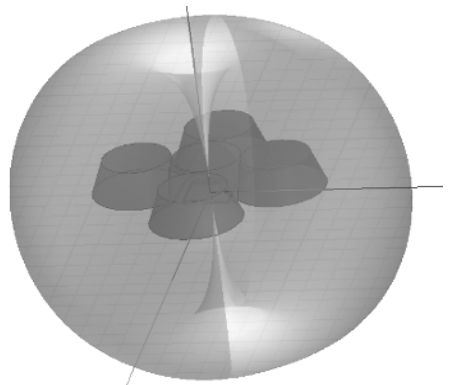

6

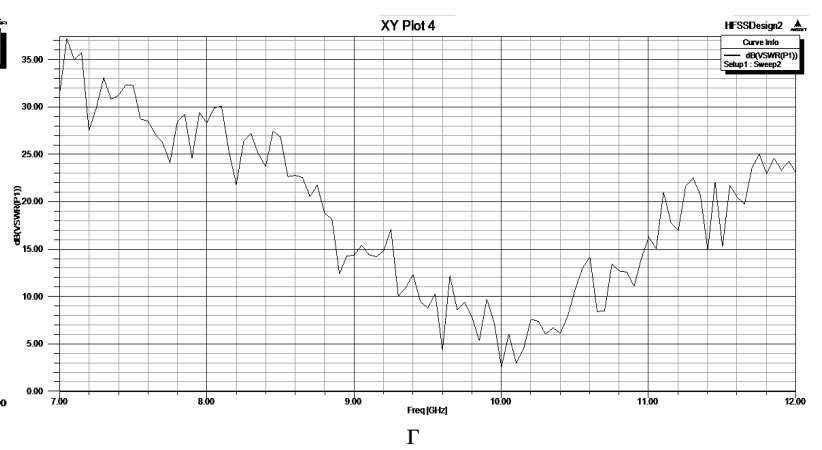

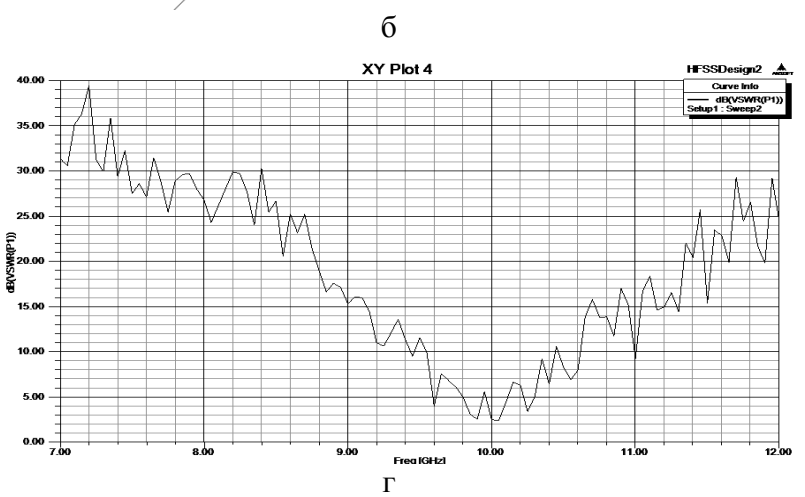

Рис. 8. Друга базова модель ДРА з перекриттям на 20 мм: а - компоновка; б - ДС; в - АЧХ; г - КСХ 
Під час досліджень був реалізований також ще один варіант діелектричної резонаторніої антени, який відповідає комбінації базових моделей антен: центральний елемент - 3 першого, а периферійні - 3 другого варіантів (рис. 9).

Такий підхід є досить перспективним, оскільки в наведеному на рис. 9 графіку АЧХ для випадку відсутності накладання периферійних та центрального елементів видно досягнення рекордного піково- го значення коефіцієнта підсилення серед усіх розглянутих вище конструкцій діелектричної резонаторніої антени.

Зазначений виграш спостерігається також за наявності перекриття АЕ, що було підтверджено зміною величини перекриття в межах від нуля до 10 мм.

Останній спосіб компоновки діелектричної резонаторніої антени відповідає рис. 10.

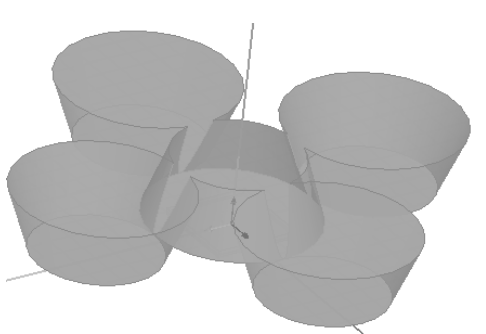

a

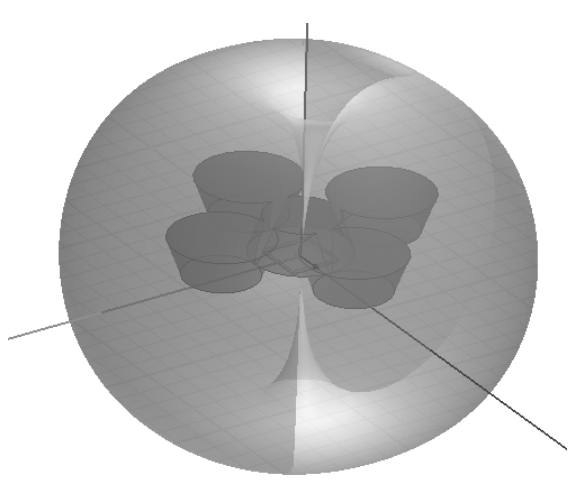

б

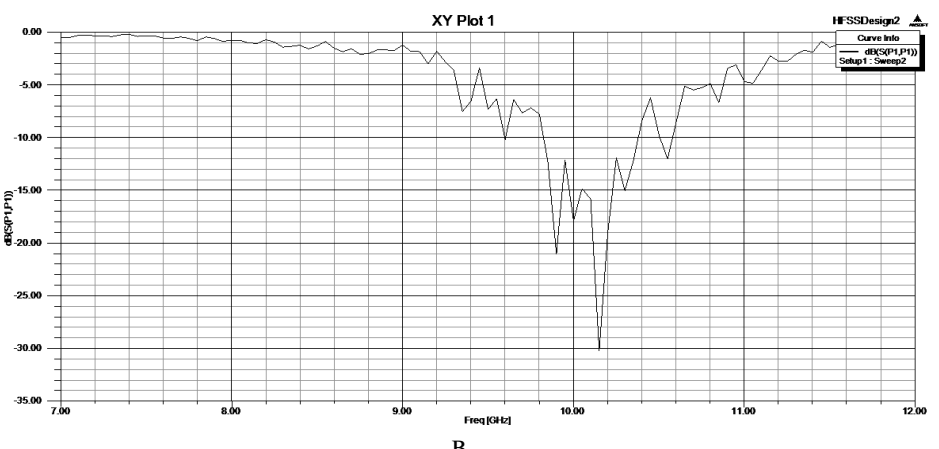

B

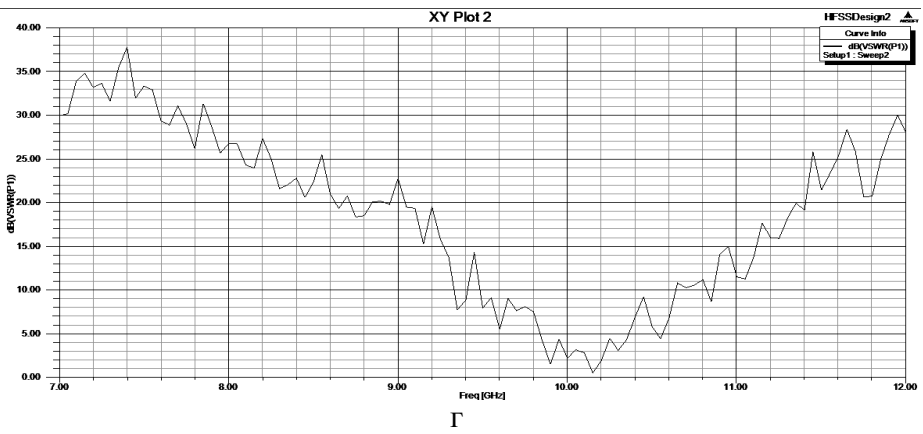

Рис. 9. Комбінаційна базова модель ДРА без накладання АЕ: a - компоновка; б - ДС; в - АЧХ; г - КСХ

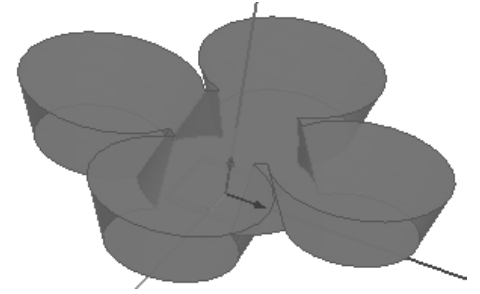

a

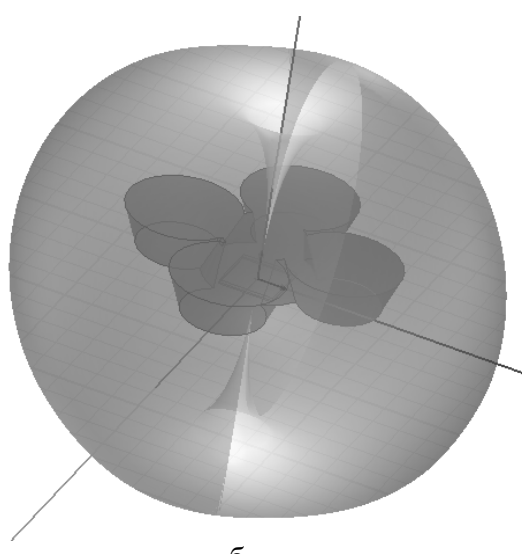

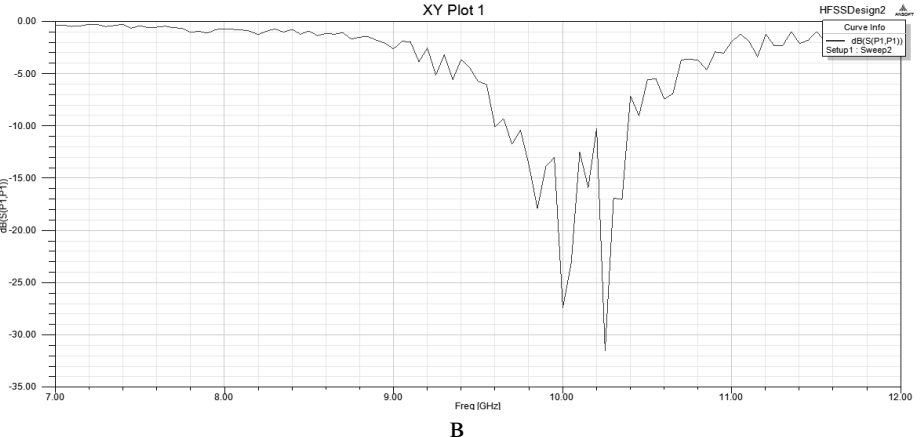

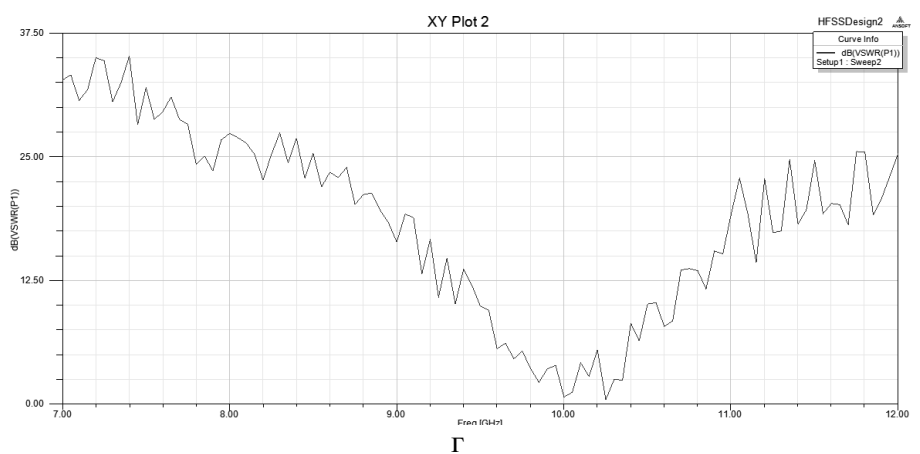

Рис. 10. Комбінаційна модель ДРА з перекриттям 10 мм: а - компоновка; б - ДС; в - АЧХ; г - КСХ 
В ході досліджень синтезовані варіанти антен аналізувались також з врахуванням наявності рефлектора. Однак, детальний опис відповідних результатів виходить за межі даної статті.

\section{Висновки}

На основі аналізу результатів моделювання можна зробити кілька висновків.

Реалізація перекриття АЕ ДРА підтвердила допущення про покращення в таких умовах просторово-частотних характеристик антени. Наприклад, в ДРА першого типу рівень підсилення зріс більше, ніж на $70 \%$, а в антенах другого типу - приблизно на $12,5 \%$

Завдяки накладанню елементів вдалося розширити смуги робочих частот ДРА.

ДС виявилися нечутливі до накладання елементів, але за потреби форму ДС можна змінити іншими шляхами, наприклад, зміною геометричних розмірів елементів антени або встановленням рефлектора.

Також треба зауважити, що розміри антен 3 накладанням елементів суттєво зменшуються, порівняно $з$ антенами без перекриття. А це є дуже важливим фактором для мінімізації розмірів електронної апаратури.

Отже в результаті накладання АЕ отримано антени, які кращі по своїм параметрам, ніж ті, що були на початку моделювання.

Подальші дослідження доцільно спрямувати на розробку моделей ДРА, які забезпечать роботу в кількох діапазонах, стандартизованих для мобільних додатків та Інтернету речей.

Потребує додаткової уваги питання визначення впливу властивостей діелектрика на значення резонансних частот ДРА, варіювання розмірами і кількістю периферійних елементів та застосування метаматеріалів [9].

\section{Список літератури}

1 Слюсар В.И. Диэлектрические резонаторные антенны. / Слюсар В.И. // Электроника: наука, технология, бизнес. - 2007. - № 2. - С. 28-37.

2. Слюсарь I.I. Імітаиійна модель квазіфрактальної 3D-антени. / Слюсарь I.I., Слюсар B.I., Миколенко О.С. // Проблеми інформатизаиіі: Тези доповідей 5-ої міжнародної НТК, 13-15 листопада 2017 р. - Черкаси - Баку Бельсько-Бяла - Полтава. - С. 80.

3. Слюсар В.И. Фрактальные антенны. / Слюсар В.И. // Радиоаматор. - 2002. - № 9. - С. 54-56.

4. Слюсар В.И. Фрактальные антенны. Приниипиально новый тип “ломаных" антенн. Часть 1 / Слюсар В.И. // Электроника: наука, технология, бизнес. 2007. - № 5. - С. 78-83.

5. Слюсар В.И. Фрактальные антенны. Принципиально новый тип «ломаных» антенн. Часть 2. / Слюсар В.И. // Электроника: наука, технология, бизнес. 2007. №. 6. - C. 82-89.

6. Потапов А.А. Генетические и самоаффинные методы проектирования фрактальных антенн / Потапов А.А., Шифрин Я.С., Кузеев Р.Р. //Антенны, 2014. - № 3. - C. $25-48$

7. Банков C.Е. Расчет антен и СВЧ структур с помощью HFSS Ansoft. / Банков С.Е., Курушин А.A. - М.: 3 АO «НПП «РОДНИК», 2009. - $256 c$.

8. Миколенко О.С. Діелектрична резонаторна антена на основі усіченого конусу. [Електронний ресурс] / Миколенко О.С., Слюсар B.I., Слюсарь I.I. // Новітні інформаційні системи та технології. - 2017. - № 8. Режим доступу:

http://reposit.pntu.edu.ua/handle/PoltNTU/3096.

9. Слюсарь I.I. Метаматеріали в антенах засобів мобільного зв'язку. / Слюсарь I.I., Слюсар B.I., Задорожний Р.С. // Проблеми інформатизаиії: Матеріали III-ої міжнародної НТК - Черкаси, ЧДТУ; Баку: ВА ЗС АР; Бельско-Бяла: УТіГН; Полтава: ПолтНТУ, 2015. - С. 54.

\section{Надійшла до редколегї 19.02.2018}

Рецензент: д-р техн. наук, проф. П.С. Пустовойтов, Полтавський національний технічний університет імені Юрія Кондратюка, Полтава.

\title{
ИССЛЕДОВАНИЕ ВЛИЯНИЯ ПЕРЕКРЫТИЯ ЭЛЕМЕНТОВ ДИЭЛЕКТРИЧЕСКИХ РЕЗОНАТОРНЫХ АНТЕНН НА ОСНОВЕ УСЕЧЁННОГО КОНУСА
}

\author{
Р.Е. Гребеля, В.И. Слюсар, И.И. Слюсарь
}

В работе рассмотрены характеристики квазифрактальных диэлектрических резонаторных антенн (ДРА) на базе усеченного конуса, в зависимости от степени наложения их элементов. Кроме того, были проведены исследования двух вариантов антенн: с большим диаметром вверху, и с большим диаметром внизу. Оценка и сравнение антенн осуществлялось по таким параметрам: амплитудно-частотная характеристика, диаграмма направленности и коэффициент стоячей волны. Оченка этих параметров проводилась с помощью пакета программ Ansoft HFSS.

Ключевые слова: антенна, АЧХ, ДН, фрактал, Ansoft HFSS, DRA.

\section{INFLUENCE OF IMPOSITION ELEMENTS DIELECTRIC RESONATOR ANTENNA BASED ON A TURNCATED CONE}

\section{R.E. Hrebelia, V.I. Slyusar, I.I. Sliusar}

In the paper, the characteristics of quasi-fractal dielectric resonator antennas based on a truncated cone were considered, depending on the degree of superposition of its elements. In addition, two versions of antennas were investigated: with a large diameter to the top, and with a large diameter to the bottom. Evaluation and comparison of antennas was carried out for such parameters: amplitude-frequency response, directivity pattern and VSWR. The evaluation of these parameters was done using Ansoft HFSS software package.

Keywords: antenna, amplitude frequency response, Ansoft HFSS, directivity pattern, DRA, fractal. 